今回の検討において累積開存率が諸家の報告に比し両 群とも低値を示したのは地域性の問題等で follow-up が 十分に行えず脱落していく症例が多く，さらに他病因で 死亡する症例む多数存在するためと考えられた.

一方，人工血管を使用すると手術時間の短縮，皮膚切 開線の節約, 術後静脈うっ滞性浮腫の減少などの利点が ある.したがって大伏在静脈の温存の目的，さらに採取 困難例の対策として考慮すると, ASO 症例の F-P バイ パス術にはリング付きグラフトを第一選択としてあよい と考えられた。

\section{結語}

F-P バイパス術 32 例 37 肢を対象とし, 16 肢に大伏
在静脈グラフトを, 21 肢にリング付き Gore-Tex グラ フトを用い比較検討した.

1) リング付き Gore-Tex グラフトの累積開存率と 大伏在静脈グラフトの累積開存率の間には，1，4 年に おいて大きな差を認めなかった。

2）両群の術後早期执よび遠隔期の臨床症状は有意に 改善し, その改善度に差はなかった。

3） ASO 症例に対する F-P バイパス術（滕上部）に はリング付き Gore-Tex グラフトを用いることの有用 性が示唆された。

文 献 1) Kurlin, J.：Arch. Mal. Coer. 42: 371, 1949. 2) 佐藤伸一ほ加: 脈管学 24:838, 1984.3$)$ 瀧本幹之ほか： 日心外会誌 17：432，1988.

\title{
68 下肢慢性動脈閉塞に対する手術手技についての検討
}

一とくに遠隔成績からみた自家静脈バイパス術と transluminal angioplasty および thin wall ringed PTFE 人工血管バイパス術との比較—

\section{大阪府立病院 心臟血管外科 \\ 加藤雅明平中俊行 大久保修和森本芳和 大西健 二}

従来, 大腿動脈以下の慢性動脈閉塞 (以下 COD) に 対するグラフト材料として自家大伏在静脈 (以下 SV) がその開存性の良好さより第一選択として使用されてき たが ${ }^{11}$ ，乙れら COD 患者は冠動脈疾患を高率飞合併 $し^{2,3)}$, CABG に備えた SV の温存が重要な問題となり つつある. これらの観点より, われわれは大腿動脈以下 の COD 症例に対し SV 温存を目的として, transluminal angioplasty (以下 TAP) あるいは PTFE 人工血管 によるバイパス手術を施行してきた，そこで今回，SV 温存乩よび TAP, PTFE 使用の妥当性をその遠隔成績 を中心に検討した.

\section{対象, 方法}

対象は 1981 年 1989 年 4 月 の期間に当科にて血行再 建を施行した COD 症例, 121 例 143 肢で, 年齢は平均 $66 \pm 10$ 歳, 男女比は $9: 2$ である. 当科では $\mathrm{COD}$ 症例 に対し, 狭窄例之同様可及的に TAP を施行し, これが 不可の場合, バイパス手術を適応としてきた. バイパス
手術のグラフト材料は初期には SV を, Gore-Tex thin wall ringed graft (以下 PRTFE) 開発.

以来, RPTFE を第一選択とした。 そこで COD 症例 に対する治療方針を次の 3 群に分類し，遠隔成績につい て検討した.

年齢 $\hat{0}:$ 우 追跡期間 (平均) SVG 群 25例28肢 $65+1224: 12$ 2 101(38.8) 月 $\mathrm{TAP}$ 群 44例48肢 $65+1035: 9 \quad 1 \sim 84$ (35.5) RPTFE 群 52例67肢 $68+9 \quad 40: 12 \quad 1 \sim 69$ (17.1) $\mathrm{TAP}$ ，あるいはバイパス術後の抗凝血治療は全例ワ ーファリンコントロールを原則としており，抗血小板製 剂についてのみ 3 群間の比較を行った。

基礎疾患については高血圧 (HT), 糖尿病 (DM), 高 脂血症 (HL), タバコをあげ, これら基礎疾患の延べ件 数を比較した.

末梢動脈の run off の指標として popliteal trifurcation 以下の開存血管本数を術前, 術中の血管造影より調 べ, 3 群間で比較した. 
TAP あるいはグラフトの閉塞は ankle pressure index の低下例に対し血管造影を施行し確認した。 3 群 の遠隔期開存率は Kaplan-Meier 法を用いて算出した.

各群間の比較は $\chi^{2}$ 椧定, generalized Wilcoxon test と Multiple compalison test を用い $p<0.05$ をむって 有意とした.

TAP 症例, および RPTFE を使用したバイパス症例 のうち, 心電四上, 明らかな異常 $\mathrm{Q}$ 波を認め, 心エコ 一上, 局所的に asynergy のあるあの, 冠動脈撮影上, $75 \%$ 以上の主要冠動脈狭窄があるものを冠動脈疾患 (CAD) と診断した.また冠動脈バイパス手術をうけた か否かをあ追跡調查した.

\section{結果}

年秢, 性差: 3 群間に年踰差, 性差は認めなかった。 抗凝血療法: 抗血小板製剂の服用頻度は SV 群で 95.6\%, TAP 群で $97 \%$, RPTFE 群で $92 \%$ といずれ あ高率で, 3 群間に有意差を認めなかった.

基礎疾患: 基礎疾患の頻度に関しては図 1 のごとく, 1 人あたり SV 群で $1.6 \pm 0.7$ 件, TAP 群で $1.2 \pm 0.8$ 件, RPTFE 群で $1.4 \pm 0.9$ 件と 3 群間で有意差を認め ず，その各内容に扔いても 3 群間で有意差を認めなかっ た.

末梢開存血管数: Popliteal trifurcation 以下の開存血 管本数は図 2 のごとく, SV 群で $2.0 \pm 1.0$ 本, TAP 群 で $2.2 \pm 0.8$ 本, RPTFE 群で $2.1 \pm 0.9$ 本と有意差は なかった. また各群の末梢開存血管本数と graft 開存 率には相関とそ認めなかったが, SV 群で開存血管本数 の増加とともに開存率が上がる傾向が認められた。

遠隔期開存率：TAP，および SV，RPTFE によるバ イパス手術の $1 ， 3 ， 5$ 年における開存率は図 3 のごと くSVG 群で 92, 75, 75\%, TAP 群で 75, 72, 65\%, RPTFE 群で 95, 91, 91\%で, SV 群-TAP 群, SV 群RPTFE 群間ではともに有意差を認めなかった，TAP

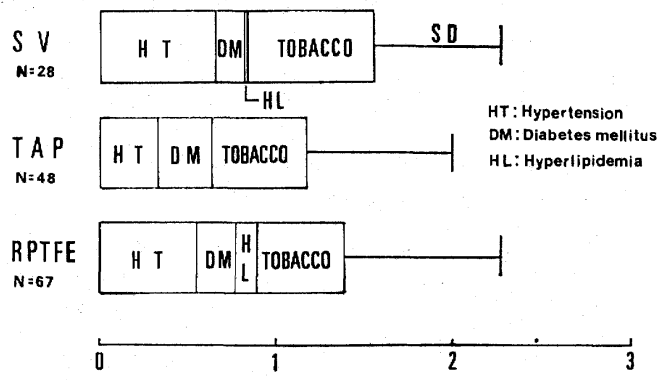

図 1 Atherosclerotic risk factors

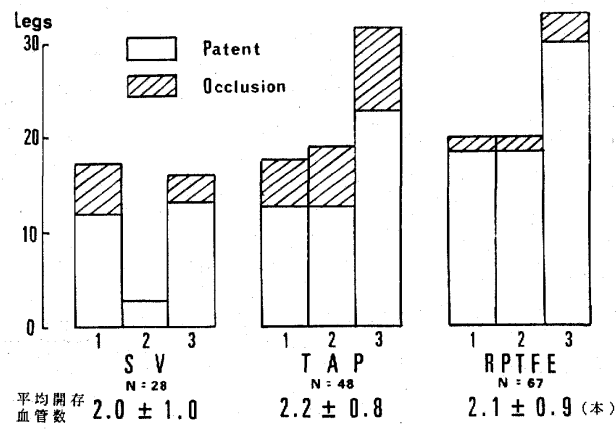

図 2 Trifurcation 以下の開存血管数之 graft patency の関係

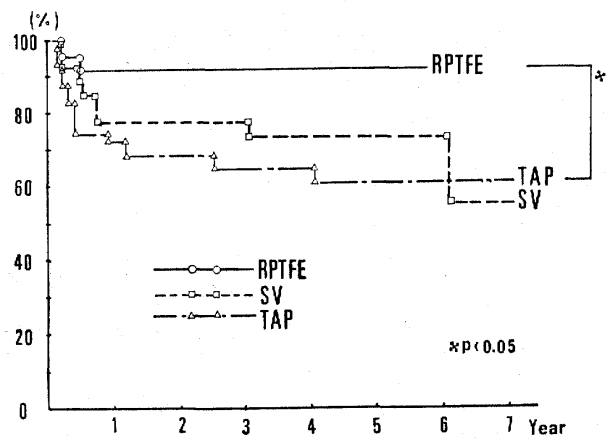

図 3 Patency curves

群-RPTFE 群間は，1，3，5 年においてその開存率 が RPTFE 群で有意に高率であった。

冠動脈疾患の合併: TAP 群, RPTFE 群を合わせた 96 症例のうち 21 例 $(22 \%)$ が冠動脈疾患之診断, うち 6 例 (6.2\%) 飞冠動脈バイパス手術を施行した.

\section{考案}

閉塞性動脈硬化症における冠動脈疾患の合併頻度は諸 家の報告では，41 62\% と比較的高值 ${ }^{2,3)}$ で，また冠動 脈バイパス術の合併頻度は $25 \%$ との報告もある ${ }^{2}$. 今 回のわれわれの検討においては，冠動脈疾患の合併 21 例 $(22 \%)$ ，冠動脈バイパス手術 6 例 $(6.2 \%)$ 乙諸家の それに比しやや低い傾向がある. これは諸家, 引用デー タが全例の冠動脈撮影を基礎としているためで, 当科に おける冠動脈撮影施行頻度（18\%）を考えるとその診断 率屯妥当といえるかもしれない，われわれは閉塞性動 脈硬化症における冠動脈疾患の高率な合併頻度を鑑み, $\mathrm{SV}$ 温存のため TAP, RPTFE グラフトを可及的に選 択してきたが，その最大の問題点は遠隔期開存性にある といえる. しかし今回のわれわれの検討においては, 
TAP こそ閉塞例を対象としたため 3 年開存率が $65 \%$ と低值であったが (狭窄例では 92\%), RPTFE 群は 3 年で $91 \%$ SVG を上回る良好な開存率を得た，乙の 成績は COD に PTFE 人工血管を使用する他家の 成績 ${ }^{4(6)}$ を上回るが，乙れは，1）Graft 材料の改善: Thin wall ringed PTFE を使用した. また吻合部に あ ring で support された部位を使用し, graft kink を 極力防止した. 2) Graft 内血流量の改善: Graft の中 枢, 末梢側の血管狭窄解除のため術中 angio 装置を使 用し angio plasty 同時施行したことによる屯のと思 われる.

$$
\text { ま と め }
$$

1）下肢慢性動脈閉塞例の SV 温存のため, TAP,
あるいは RPTFE による bypass 手術を施行したが，そ の遠隔開存に㧧いて SV による bypass 手術と有意差を 認めなかった.

2) RPTFE の graft 開存率は 3 年で $91 \%$ と TAP に比し有意に良好で，下肢慢性動脈閉塞に対する first choice の graft 材料と考える.

文 献 1) Yeanger, R. A. et al.: Surgery 91: 99, 1982. 2) Hertzer, N.R. et al.: Ann. Surg. 199: 223, 1984 . 3) Tomatis, L. A. et al.: Surgery 71: 429, 1972. 4) McAury, C. E. et al.: Ann. Surg. 199: 57, 1984. 5) Quinones-Baldrich, W. J. et al.: Arch. Surg. 119: 1238, 1984. 6) Wi1liams, G. T. et al. : Ann. Vasc. Surg. 1: 208, 1986.

\title{
695 年以上経過した Gore-Tex による bypass 手術症例の検討
}

\author{
松阪中央総合病院 胸部外科
}

\section{滝 喜 一 山崎 順彦}

閉塞性動脈硬化症 (以下 ASO) に対し, 種々の graft を用いた bypass 手術が施行され良好な成績が示されて いるが，その長期予後については未だ多くの問題を含む あのと思われる. そこで, われわれの施設で施行した ASO に対する Gore-Tex を用いて bypass 手術症例の うち, 手術後 5 年以上経過した症例をとり上げ検討した ので報告する.

\section{対象および成績}

われわれの施設で施行した ASO に対する Gore-Tex を用いた bypass 手術症例は aorto-femoral bypass 26 例, femoro-popliteal bypass 27 例, femoro-femoral bypass 18 例, 合計 71 例である. 全例に術後ワーファリ ンによる抗凝固療法を長期にわたって行い, 理学所見と ともに, angiography $ゃ$ RI angiography で bypass graft の開存状態を確認しながら, 術後最長 10 年経過 観察している.

Aorto-femoral bypass 26 例中 13 例が手術後 5 年以 上経過し，13 例中 10 例は良好に開存し，2例に閉塞を
きたし，1例は心筋梗塞により死亡している.

Femoro-popliteal bypass 症例では, 27 例中 15 例が 術後 5 年以上経過し，15 例中 10 例は良好に開存し，閉 塞例は 3 例で, 他の 2 例は心筋梗塞および脳梗塞で死亡 している.

Femoro-femoral bypass 症例では, 18 例中 7 例が術 後 5 年以上経過し, 全例良好に開存している.

5 年以上開存例は aorto-femoral bypass 13 例中 10 例, femoro-popliteal bypass 15 例中 10 例, femorofemoral bypass 7 例中 7 例, 合計 35 例中 27 例開存, 開存率 $77 \%$ である(表 1 ).

閉塞をきたした 5 例は，いずれす，bypass graft の末

表 1 Gore-Tex による bypass 手術症例 (術後 5 年以上経過症例)

\begin{tabular}{cr}
\hline Aorto-femoral bypass & 13 例 $(10)$ \\
Femoro-popliteal bypass & 15 例 $(10)$ \\
Femoro-femoral bypass & 7 例 $(7)$ \\
\hline 棓 & 35 例 $(27)$ \\
\hline ( ) 開存例 &
\end{tabular}

